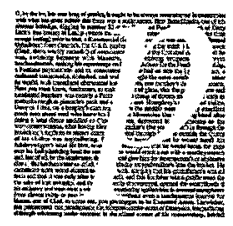

\title{
Historia y memoria en la poética de Balún Canán ${ }^{1}$ Françoise Perus
}

\author{
Instituto de Investigaciones Sociales \\ Universidad Nacional Autónoma de México
}

\begin{abstract}
A menudo la lectura de Balún Canán (1957) ha sido asociada con aquella niña, algo voluntariosa, que al principio de la novela aparece resistiendo los cuidados de su nana indígena y lidiando con las prerrogativas de su hermano - menor, pero varón al fin y al cabo-y que, adolorida luego por la pérdida de ambos, se prepara desde la otra orilla del tiempo y el texto para rescatar las vivencias pasadas por medio de la escritura. Sin duda, éstas y otras muchas pérdidas constituyen un tema medular en la primera novela de Rosario Castellanos; y sin duda también estas mismas pérdidas guardan cierta correspondencia con la biografia de la narradora chiapaneca. Pero aun cuando la escritura, figurada al final de la novela como anticipación y refrendo de la forma de la narración en primera persona, se presenta efectivamente como respuesta ineludible a la pérdida de la infancia y el mundo familiar y social, lo fundamental sigue siendo la forma concreta en que esta misma escritura elabora la pérdida de dicho mundo, y el modo en que busca involucrar en ello a su lector. Todo en la novela no está narrado en el mismo plano; ni por la misma voz; las dos partes narradas en primera persona - la primera y la tercera- mezclan tiempos presentes y pasados, y la parte central del
\end{abstract}

Poligrafias IV (2003) 31-5I

(C) Poligrafias. Revista de Literatura Comparada. División de Estudios de Posgrado, Facultad de Filosofia y Letras, Universidad Nacional Autónoma de México, Ciudad Universitaria, México 04510 DF. Tel. (525) 622 1835(6). Fax (525) 622 1801; $6160047 ; 6221826$. 
relato, narrada en pasado, pertenece a una voz en tercera persona, cuya relación con la anterior resulta algo enigmática.

\section{La forma del tríptico como principio composicional}

Cronológicamente hablando, los acontecimientos que se narran en Balún Canán definen tiempos y espacios precisos, lo cual a su vez subraya la tripartición de la novela: la evocación de la vida familiar en la casa de Comitán primero; el traslado de los Argüello a Chactajal, con el relato de la sublevación indigena en la parte central; y por último, el regreso a Comitán, marcado por la ausencia del padre, el despido de la nana y la muerte del hermano menor. En este primer nivel al menos -el de la distribución cronológica de los tiempos y los espacios en que se juega la suerte de la familia de la protagonista-, la novela hace pensar en un tríptico, cuya primera hoja evocaría la atmósfera de la casa familiar, con la niña en el centro, rodeada de la nana, el hermano menor y la madre, todos bajo la presencia tutelar del padre; la hoja central destacaría el levantamiento indígena en contra del hacendado, y la dispersión de la casta familiar; y la hoja de la derecha rememoraría la zozobra de las mujeres (y la de la madre en particular) en ausencia de la figura tutelar del padre, el despido de la nana, y la muerte del hijo varón.

Si bien en la hoja central de este tríptico la niña pudiera estar ausente, o no figurar sino de modo totalmente marginal aunque no por ello carente de valor simbólico -extraviada, embargada por el llanto, y privada de voz-, en la tercera hoja tendría acaso que figurar dos veces: una primera vez en trasfondo, escondiendo la llave del oratorio en el baúl de la nana, y luego en primer plano, abajo y a la derecha, como queriendo salirse del cuadro aunque sin dejar de mirarlo, y sosteniendo el lápiz (o el pincel) en la pequeña mano todavía inhábil.

Esta imagen de un retablo en forma de tríptico se nos impuso al buscar un equivalente visual de la organización formal del relato, y después de descartar la de un fresco social o de un mural, por cuanto éste hubiera impuesto al texto una unidad composicional y estilística en buena medida ajena a él. De hecho, sólo el relato central de la rebelión indigena, de la derrota del hacendado y de la dispersión de la casta familiar, podría evocar, al menos hasta cierto punto, aquellas formas de narración realista, que tanta fuerza habían tenido, décadas antes, en la narrativa, en la pintura y en el cine mexicanos. Las otras dos partes son demasiado reducidas en extensión y trazos, demasiado dispersas, y sobre todo demasiado ajenas al tono de aquel relato central, como para pensar que el orden cronológico que une a los tres unidades narrativas (antes y después de la tragedia de Chactajal) pudiera dar cuenta, por sí solo, de la organización formal de la obra; o mejor dicho, para que esta sucesión cronológica y los acontecimientos que evoca sean los que proporcionan su unidad composicional a la novela. El tríptico, en cambio, permite imaginar otras formas de organización, otros movimientos del texto, y otras formas de circulación del sentido. Vale decir, otra propuesta de lectura.

Sin cancelar la unidad cronológica subyacente, la imagen de un tríptico devuelve a cada una de las tres partes la indudable autonomía que les confiere el hecho primordial 
de estar narradas en tiempos distintos, y de no estar todas en boca del mismo narrador. Mientras la parte central está relatada en pasado y en tercera persona por un narrador que no se halla involucrado en los sucesos narrados, las otras dos pertenecen a una voz en primera persona que entrelaza la de la niña de ayer con la de la narradora de hoy. Si bien el "yo" de la primera persona gramatical permite entender que la protagonista y la narradora son una misma persona fisica, el empleo predominante de un tiempo presente podría dejar suponer que es la niña la que se halla narrando. Sin embargo, desplazamientos de registro y acento muy sutiles en la primera parte, y apariciones esporádicas de tiempos verbales pasados en la última, muestran a las claras que, aun cuando la narradora se confunde a menudo con la niña que fue, suele también distanciarse de ella, o verla desde el ahora de la narración. Esta particularidad de la voz enunciativa queda sentada desde el principio mismo de la novela:

No soy un grano de anís. Soy una niña y tengo siete años. Los cinco dedos de la mano derecha y dos de la izquierda. Y cuando me yergo puedo mirar de frente las rodillas de mi padre. Más arriba no. Me imagino que sigue creciendo como un gran árbol y que en su rama más alta está agazapado un tigre diminuto. Mi madre es diferente. Sobre su pelo - tan negro, tan espeso, tan crespo- pasan los pájaros y les gusta y se quedan. Me lo imagino nada más. Nunca lo he visto. Miro lo que es a mi nivel. Ciertos arbustos con las hojas carcomidas por los insectos; los pupitres manchados de tinta; mi hermano. Y a mi hermano lo miro de arriba abajo. Porque nació después de mí y, cuando nació, yo ya sabía muchas cosas que ahora le explico minuciosamente. por ejemplo ésta:

Colón descubrió la América.

Mario se queda viéndome como si el mérito no me correspondiera y alza los hombros con gesto de indiferencia. La rabia me sofoca. Una vez más cae sobre mi todo el peso de la injusticia. (9-10; el subrayado es nuestro)

Ahora bien, esta particularidad de la voz narrativa en las hojas laterales del tríptico subraya a su vez el hecho de que la parte central no está asumida por la misma narradora, sino que está atribuida a un "se" impersonal respecto del cual pareciera existir un distanciamiento máximo, no sólo por parte de la niña sino también de la narradora. Este contraste insólito se halla recalcado, de otra forma, por el hecho de que, en este relato central y distanciado, la niña sólo aparece muy fugazmente, y como si se tratara de otra persona (no como el "yo" anterior, sino como un personaje episódico y marginal): una primera vez, alejada de los acontecimientos, perdida y privada de voz por el llanto que la embarga; y luego, muda también, con ocasión del baño al que llevan a los niños en el río, y que se describe así:

...(Zoraida) condujo a la niña al río y, con el fin de darle confianza, fue tanteando la hondura que pisaba y la sostenía a flote cuando un desnivel demasiado brusco de terreno abría, bajo los pies de la criatura, un pequeño abismo.

- ¿Quieres nadar?

La niña asintió castañeando los dientes de frío. Entonces Matilde se aproximó hasta donde el agua amenazaba mojar sus zapatos y desde allí estiró los brazos para entregar el par de tecomates. Cuando la niña los tuvo atados a la espalda, sostenida más que por ellos por la certeza de que no se hundiría, nadó. Bajo la vigilancia de su madre, iba y 
venía, sin salir de los límites de esta poza donde el agua se remansaba mientras la corriente seguía, más allá, atropellándose, bramando. (148-149)

La poza de agua remansada, en donde la nịna nada mientras allá brama la corriente, metaforiza la distancia subjetiva respecto de los acontecimientos - la corriente bramando y atropellándose - que constituyen el núcleo narrativo de esta hoja central. Señala asimismo la diferencia fundamental de registro enunciativo que atañe a la composición de los diferentes episodios: mientras el del medio se centra ante todo en las acciones, los comportamientos y las motivaciones de los protagonistas del enfrentamiento entre indígenas y hacendado, los otros dos recrean atmósferas, sensaciones y vivencias. De tal suerte que lo que en las hojas laterales del tríptico aparece primordialmente como reminiscencias y actualización del pasado por obra de una memoria ante todo evocativa y abierta a la exploración de viejos y nuevos significados, contrasta violentamente con la otra memoria del relato central, consolidada y fijada por la forma de la narración "histórica," en pasado y en tercera persona.

Es así como la imagen del tríptico nos ha parecido la más apta para dar cuenta a la vez de la unidad cronológica de los tres episodios (antes y después de Chactajal), de su distribución triangular (con una hoja central que en términos del espacio textual ocupa un lugar equivalente al de las dos hojas laterales juntas), y del contrapunto que, pese al equilibrio clásico de esta composición, dejan entrever las profundas diferencias de punto de vista y de estilo narrativo que separan la hoja central de las dos laterales. A nuestro juicio, esta misma figuración visual contribuye también a destacar un principio composicional esencialmente dual. Dicho principio conjuga el equilibrio triangular del conjunto con la diferenciación de los planos narrativos de cada hoja, y permite al mismo tiempo que las evocaciones de la niña y las reminiscencias de la narradora puedan seguir dialogando desde ambos lados de la reconstrucción histórica e impersonal de los acontecimientos de Chactajal. Pero sugiere también el movimiento y los trayectos de sentido que han de guiar la reflexión del lector, luego de que éste se haya dejado llevar por la sucesión cronológica de los acontecimientos narrados o las escenas evocadas. Y por último, al destacar juntas la unidad argumental y la contraposición de formas narrativas asociadas con modalidades distintas de la memoria (la del relato histórico y la de la reminiscencia vivencial), el tríptico llama a una reflexión acerca del valor arquitectónico - en el sentido bajtiniano de la palabra - de una forma composicional que reúne modalidades enunciativas tan contrapuestas. En efecto, pareciera que, pese a su posición meridiana, su anchura, su altura y su tono mayor, el plano central tuviera que situarse en trasfondo, en tanto que, desde las hojas laterales, las reminiscencias actuales estuvieran señalando perspectivas oblicuas sobre los acontecimientos centrales de Chactajal. Pero no sólo eso: con sus perspectivas oblicuas, las hojas laterales podrían estar perfilando también una suerte de vis à vis - e incluso de diálogo-, que tuviera al relato histórico central por referente implícito, e involucrara juntas a la niña de ayer y a la narradora de hoy, e incluso al lector virtual. 


\section{Dos herencias contrapuestas y enlazadas: Historia, memoria e identidad}

Esta reubicación del lector frente a trayectos de sentido sin duda complejos, y las interrogantes que tiene que suscitar la contraposición de formas narrativas asociadas con modalidades diferenciadas de vinculación con el pasado - con la historia y con la memoria - orientan la atención hacia las otras muchas formas que tiene el texto de figurar esta vinculación. En efecto, con la evocación liminar de El libro del consejo $-\mathrm{y}$ antes mismo del inicio del relato familiar--, la novela enmarca la problemática de los vínculos inciertos entre historia y memoria dentro de una temporalidad más vasta, que abarca la época prehispánica, la Conquista y el periodo colonial:

Musitaremos el origen. Musitaremos solamente la historia, el relato.

Nosotros no hacemos más que regresar; hemos cumplido nuestra tarea; nuestros días están acabados. Pensad en nosotros, no nos borréis de vuestra memoria, no nos olvidéis.

Aunque algo enigmática, esta apelación inicial a El libro del consejo señala de entrada cierta discontinuidad entre, por un lado, "el origen, la historia, el relato" - "musitados" apenas por los vencidos - y, por el otro, lo que se anticipa como la "memoria" futura de los vencedores. Bajo una forma algo distinta, aunque claramente asociada esta vez con "la palabra" - es decir, con el lenguaje y la voz-, esta misma discontinuidad es retomada por el diálogo entre la nana indígena y la protagonista con que principia la novela:

... - Y ENTONCES, coléricos, nos desposeyeron, nos arrebataron lo que habíamos atesorado: la palabra, que es el arca de la memoria. Desde aquellos días arden y consumen con el leño en la hoguera. Sube el humo en el viento y se deshace. Queda la ceniza sin rostro. Para que puedas venir tú y el que es menor que tú y les baste un soplo, solamente un soplo...

No me cuentes ese cuento, nana.

- ¿Acaso hablaba contigo? ¿Acaso se habla con los granos de anis? (9)

Por lo mismo, tampoco resulta casual que la superioridad en el saber, que la niña quiere marcar respecto de su hermano menor, se señale a partir de lo aprendido en la escuela acerca de la historia de América:

Y a mi hermano lo miro de arriba abajo. Porque nació después de mi y, cuando nació, yo ya sabía muchas cosas que ahora le explico minuciosamente. por ejemplo ésta:

Colón descubrió la América (9-10)

A partir de esta configuración inicial del vínculo entre historia, memoria, lenguaje y voz, y de la contraposición más o menos explícita del "cuento" de la nana (que la niña no quiere oír) con la frase perentoria aprendida en la escuela, la novela se desenvuelve apelando a diversas formas y registros narrativos que evocan sucesos que, de una u otra manera, conjugan la historia familiar con la herencia prehispánica y colonial.

Entre estos registros y estas formas se encuentran en primer lugar los cuentos. En tanto forma de narración esencialmente oral y asentada en tradiciones mitológicas, los 
cuentos proporcionan sistemas de imágenes y representaciones "poéticas" que alimentan la imaginación de la niña y la de la narradora. Entrañan asimismo una concepción particular del tiempo -más cíclica y ambivalente que propiamente circular-que sirve de base para una serie de analogias y entrecruzamientos entre los ciclos propios de ámbitos y seres particulares. Así por ejemplo, el cuento del "dzulúm," relatado por la nana en el capítulo VI, cumple conjuntamente con la función de anticipar la suerte de Matilde en el episodio central ("Ella lo miró y fue tras él como hechizada"), y con la de enlazar estas historias particulares - la que refiere el cuento y la de Matilde- con la concepción cíclica que subyace también en El libro del Consejo. Con base en el mismo principio de analogía, trasladado esta vez de lo individual a lo colectivo, el desenlace del cuento -que sintetiza y anticipa a su modo el destino de Matilde y Ernesto ("Y un paso llamó al otro paso y así hasta donde se acaban los caminos. El iba adelante, bello y poderoso, con su nombre que significa ansia de morir," 21) - recuerda también al "Nosotros no hacemos más que regresar; hemos cumplido nuestra tarea; nuestros días están acabados" del liminar que encabeza la novela. Pero esta misma analogía remite a su vez a otro liminar, extraído del Chilam-Balam de Chumayel y colocado antes del inicio del relato central:

Toda luna, todo año, todo día, todo viento camina y pasa también. También toda sangre llega al lugar de su quietud, como llega a su poder y a su trono. (75)

De tal suerte que, en el marco de la temporalidad cíclica así configurada tanto por la memoria indígena escrita como por los cuentos de la nana, la historia familiar - y en particular la pérdida del dominio sobre las tierras de Chactajal-puede leerse como el cumplimiento de un ciclo, que se inició con la Conquista y acarreó el ocaso de la civilización indígena. Pero en este mismo marco puede leerse también el debilitamiento del orden señorial-patriarcal, con lo que conlleva de dominio del varón sobre la mujer. En efecto, la ausencia del padre y la muerte del hijo varón en la tercera parte de la novela, con el consiguiente predominio de las mujeres y con la prefiguración de la asunción de una voz femenina en la literatura, dejan entrever la posibilidad de un nuevo ciclo histórico-vital, en donde otros pudieran ser el lugar y el papel asumidos por la mujer.

Al lado de los cuentos de la nana y de los del "tío David" - quien, pese a no ser indio, comparte con aquélla el repertorio mitológico prehispánico que ambos conjugan con la mitología cristiana y algunas figuras de procedencia colonial - destaca, en la primera parte de la novela, otra forma de vincular el pasado prehispánico y colonial con el presente histórico. Nos referimos al manuscrito del "hermano mayor de la tribu" (cap. XVIII), hallado por la niña en medio de manojos de cartas, retratos familiares sin nombres ni fechas, y cuentas ininteligibles; esto es, entre huellas inconexas del pasado familiar. Dicho manuscrito, cuya forma recuerda - al menos en parte - la de ciertas crónicas, confiere orden y significado a éstas y otras huellas del pasado indígena y familiar, convirtiéndolo en historia, genealogía y memoria de casta.

Sin embargo, antes mismo de que el lector se entere de que este documento es apócrifo y ha sido dictado por el padre con el fin de ampararse contra la política agraria 
de Lázaro Cárdenas, el manuscrito produce cierta sensación de extrañeza, por cuanto conjuga tonos y acentos claramente distintos. Al inicio, éstos parecieran estar apelando a la memoria indígena ("Yo soy el hermano mayor de mi tribu. Su memoria." 57), y bien pudieran evocar algunas formas ligadas a esta tradición (la del Chilam Balam por ejemplo). Pero en cuanto el documento se refiere a la sucesión de los Argüello y al afianzamiento del dominio de éstos sobre las tierras de Chactajal, el tono se transforma y la narración se orienta hacia la conformación de una sucesión cronológica y caracteriza a los distintos protagonistas de la gesta familiar de tal modo que, por debajo de cierto ritmo o acento "indigena," se percibe claramente la presencia de otro registro, ajeno a la voz del supuesto narrador:

Una huérfana, una recogida, como entonces se dijo, fue la heredera. Pues asistió la agonía del moribundo. Otilia. Otros parientes más allegados le disputaron la herencia y fue entonces cuando los lugares remotos ya no pudieron ser defendidos. $Y$ así se perdió el potrero de "Rincón Tigre." Y también el de "Casa del rayo." Otilia, diestra en el bordado, adornó el manto que cubre a la Virgen de la ermita. A llamamiento suyo, el señor cura de Comitán vino a bautizar a los niños y casar a las parejas amancebadas. Desde que Otilia nos amadrinó todos nosotros llevamos nombres de cristiano. Por matrimonio ella llegó a usar el apellido de Argüello. Su lecho sólo dio varones y entre sus hijos dejó repartida la hacienda. Así también nosotros fuimos dispersados en poder de diferentes dueños. $Y$ es aquí. hermanos míos menores, donde nos volvemos a congregar. En estas palabras volvemos a estar juntos, como en el principio, como en el tronco de la ceiba sus muchas ramas. (59-60)

La hibridación deliberada de la forma y el estilo en esta crónica histórica y familiar se halla reforzada por otro lado mediante la interpretación de las distintas fases de la expropiación indígena en términos de "expiación" y "castigo," más propios del cristianismo colonial que del abandono en que, se dice, sus propios dioses dejaron a los indigenas. Y, a su vez, la "expiación" y el "castigo" se conjugan con una concepción circular - y ya no cíclica del tiempo- que termina devolviendo a los indigenas a sus propios orígenes:

Asi también nosotros fuimos dispersados en poder de diferentes dueños. Y es aquí, hermanos míos menores, donde nos volvemos a congregar. En estas palabras volvemos a estar juntos, como en el principio, como en el tronco de la ceiba sus muchas ramas. (60)

De modo que en lo que se pretende memoria, palabra y voz del indigena, asoma la perspectiva del criollo dueño de las tierras de Chactajal. Por ello es que, pese a sus ambigüedades, aquel "documento" puede representar "la herencia de Mario, del varón" $(60)$, pero no la de la niña, que no sólo no tiene derecho a heredar, sino que lucha confusamente con el orden patriarcal.

Ahora bien, esta "memoria del hermano mayor," fijada por la letra de aquella crónica histórico-genealógica de tiempos pretéritos y sellados, contrasta con la forma en que, dos capítulos más adelante (cap. XX), los temas del "hermano mayor" y de la "memoria" son retomados por la nana, la niña y la narradora. A diferencia del relato genealógico anterior, leído por la niña y citado entre comillas(y por ende no asumido 
de Lázaro Cárdenas, el manuscrito produce cierta sensación de extrañeza, por cuanto conjuga tonos y acentos claramente distintos. Al inicio, éstos parecieran estar apelando a la memoria indígena ("Yo soy el hermano mayor de mi tribu. Su memoria." 57), y bien pudieran evocar algunas formas ligadas a esta tradición (la del Chilam Balam por ejemplo). Pero en cuanto el documento se refiere a la sucesión de los Argüello y al afianzamiento del dominio de éstos sobre las tierras de Chactajal, el tono se transforma y la narración se orienta hacia la conformación de una sucesión cronológica y caracteriza a los distintos protagonistas de la gesta familiar de tal modo que, por debajo de cierto ritmo o acento "indígena," se percibe claramente la presencia de otro registro, ajeno a la voz del supuesto narrador:

Una huérfana, una recogida, como entonces se dijo, fue la heredera. Pues asistió la agonia del moribundo. Otilia. Otros parientes más allegados le disputaron la herencia y fue entonces cuando los lugares remotos ya no pudieron ser defendidos. $Y$ asi se perdió el potrero de "Rincón Tigre." Y también el de "Casa del rayo." Otilia, diestra en el bordado, adornó el manto que cubre a la Virgen de la ermita. A llamamiento suyo, el señor cura de Comitán vino a bautizar a los niños y casar a las parejas amancebadas. Desde que Otilia nos amadrinó todos nosotros llevamos nombres de cristiano. Por matrimonio ella llegó a usar el apellido de Argüello. Su lecho sólo dio varones y entre sus hijos dejó repartida la hacienda. Así también nosotros fuimos dispersados en poder de diferentes dueños. $Y$ es aquí. hermanos míos menores, donde nos volvemos a congregar. En estas palabras volvemos a estar juntos, como en el principio, como en el tronco de la ceiba sus muchas ramas. (59-60)

La hibridación deliberada de la forma y el estilo en esta crónica histórica y familiar se halla reforzada por otro lado mediante la interpretación de las distintas fases de la expropiación indigena en términos de "expiación" y "castigo," más propios del cristianismo colonial que del abandono en que, se dice, sus propios dioses dejaron a los indígenas. Y, a su vez, la "expiación" y el "castigo" se conjugan con una concepción circular - y ya no cíclica del tiempo - que termina devolviendo a los indígenas a sus propios orígenes:

Asi también nosotros fuimos dispersados en poder de diferentes dueños. $Y$ es aquí, hermanos míos menores, donde nos volvemos a congregar. En estas palabras volvemos a estar juntos, como en el principio, como en el tronco de la ceiba sus muchas ramas. (60)

De modo que en lo que se pretende memoria, palabra y voz del indígena, asoma la perspectiva del criollo dueño de las tierras de Chactajal. Por ello es que, pese a sus ambigüedades, aquel "documento" puede representar "la herencia de Mario, del varón" (60), pero no la de la niña, que no sólo no tiene derecho a heredar, sino que lucha confusamente con el orden patriarcal.

Ahora bien, esta "memoria del hermano mayor," fijada por la letra de aquella crónica histórico-genealógica de tiempos pretéritos y sellados, contrasta con la forma en que, dos capítulos más adelante (cap. XX), los temas del "hermano mayor" y de la "memoria" son retomados por la nana, la niña y la narradora. A diferencia del relato genealógico anterior, leído por la niña y citado entre comillas(y por ende no asumido 
por la narradora), la reminiscencia - en tiempo presente - de la escena en la que la nana se despide de "su niña" consiste en una evocación de la voz y la actitud de aquélla, señalando así la proximidad y la continuidad subjetivas entre la nana, la niña de ayer y la narradora de hoy. En efecto, pese al paralelismo temático-formal entre los dos capitulos a los que nos estamos refiriendo, salta a la vista una oposición radical entre ellos en cuanto a la forma en que cada uno establece la relación entre la voz narrativa y la palabra del "otro": al distanciamiento máximo de la narradora respecto de la crónica histórico-genealógica del "hermano mayor," se contrapone su cercanía afectiva respecto de la voz y la encomienda de la nana.

Por otra parte, el contrapunto implícito entre ambos capitulos se halla subrayado por el hecho de que la nana retoma, sin saberlo, los términos de aquella crónica histórico-genealógica, confiriéndoles una orientación radicalmente distinta. "Yo soy el hermano mayor de mi tribu. Su memoria" (57) empezaba la crónica; "Tú le reservarás también el ánimo de hermano mayor, de custodio, de guardián —ruega la nana-. Tú le reservarás la balanza que pesa las acciones. Para que pese más su paciencia que su cólera. Para que pese más su compasión que su justicia. Para que pese más su amor que su venganza." (63). De tal suerte que, con base en la reiteración de la apelación al "hermano mayor," las que se confrontan aquí son dos concepciones distintas de la identidad: mientras la primera descansa en el rango y el poder y se autoatribuye el dominio sobre la memoria y la palabra, la segunda se funda en el "ánimo," en el "entendimiento" ("abre su entendimiento, ensánchalo, para que pueda caber la verdad"), en la ecuanimidad ("la balanza que pesa las acciones"), y en la "gratitud" ("Para que nunca le falte gratitud"); esto es, en la asunción y puesta en práctica de un conjunto de valores que reúnen y proyectan hacia adelante la justa comprensión vivencial del presente y el pasado. A la identidad conferida, y fijada, por la ubicación dentro de la estructura social, responde una identidad abierta y en proceso, congruente con valores que, aun cuando hagan también referencia explícita al cristianismo, confieren a éste un sentido y una orientación totalmente opuestos: lejos de asociarse con el mantenimiento de la dominación mediante nociones como las de "castigo" y "expiación," el cristianismo de la nana se vincula a la par con las fuerzas de la. naturaleza ("Que la piedra no se vuelva en su contra y la golpee. Que no salte la alimaña para morderla. Que el relámpago no enrojezca el techo que la ampare," 62) y con el Dios Creador del mundo, concebido por ella — de manera bastante paradójicacomo el Dios samaritano, piadoso y justo, desconocido, o casi, por la Colonia :

Apiádate de sus ojos. Que no miren a su alrededor como miran los ojos del ave de rapiña.

Apiádate de sus manos. Que no las cierre como el tigre sobre su presa. Que las abra para dar lo que posee. Que las abra para recibir lo que necesita. Como si obedeciera tu ley.

Apiádate de su lengua. Que no suelte amenazas como suelta chispas el cuchillo cuando su filo choca contra otro filo.

Purifica sus entrañas para que de ellas broten los actos no como la hierba rastrera, sino como los árboles grandes que sombrean y dan fruto. (63) 
Al trasladarse del ámbito de las relaciones de poder y la fijación por el rango dentro de la estructura social al de la congruencia ética con el orden del mundo, a la vez natural y cristiano, la identidad del "hermano mayor" puede traspasar entonces hasta la frontera marcada por la diferencia social de sexos: no es para Mario, sino para la niña, que la nana pide a Dios "el ánimo de hermano mayor," cuestionando así la jerarquía implícita en la sentencia de la madre - "esto es la herencia de Mario, el varón"- que, en el capítulo anterior, ponía punto final a la lectura del manuscrito por parte de la niña.

Estas diferencias fundamentales en la concepción de la identidad se conjugan a su vez con formas y funciones diferenciadas de la memoria: al recuento cronológico de confrontaciones y exacciones - que sellan pasado y futuro y desembocan en una circularidad fatal-, el ruego de la nana opone la asimilación de vivencias y experiencias pasadas o presentes, y "la balanza que pesa las acciones" propias o ajenas. Pero esta evaluación ha de ser con verdad, con justicia, con humildad, y sobre todo, con gratitud para con la civilización indígena sacrificada: "Que palpe los muros de su casa, verdaderos y sólidos. Esto es nuestra sangre y nuestro trabajo y nuestro sacrificio"(64). Esta última observación nos devuelve, como lectores, a otro cuento de la misma nana, cuyos contenidos contribuyen a reforzar el sentido de la plegaria actual. En un capítulo anterior (cap. IX), dicho cuento relataba la creación del hombre y el origen de las desigualdades entre los seres humanos, y terminaba realzando las obligaciones de cada quien:

Mientras tanto en la tierra, los hombres de carne, estaban en un ir y venir, como las hormigas. Ya habian aprendido cuál es la fruta que se come, con qué hoja grande se resguarda uno de la lluvia y cuál es el animal que no muerde. Y un dia se quedaron pasmados al ver enfrente de ellos al hombre de oro. Su brillo les daba en los ojos y cuando lo tocaron, la mano se les puso fría como si hubieran tocado una culebra. Se estuvieron allí, esperando que el hombre de oro les hablara. Llegó la hora de comer y los hombres de carne le dieron un bocado al hombre de oro. Llegó la hora de partir y los hombres de carne fueron cargando al hombre de oro. Y día con día la dureza de corazón del hombre de oro fue resquebrajándose hasta que la palabra gratitud que los cuatro señores habían puesto en él subió a su boca.

Los señores despertaron al escuchar su nombre entre las alabanzas. Y miraron lo que habia sucedido en la tierra durante su sueño. $Y$ lo aprobaron. $Y$ desde entonces llaman rico al hombre de oro y pobres a los hombres de carne. $Y$ dispusieron que el rico cuidara y ampara al pobre por cuanto que de él había recibido beneficios. Y ordenaron que el pobre respondería por el rico ante la cara de la verdad. Por eso dice nuestra ley que ningún rico puede entrar al cielo si un pobre no lo lleva de la mano. (30)

En el conjunto de transcodificaciones que intentamos poner de relieve, se hallan involucrados dos sistemas culturales separados y enfrentados entre sí. Sin embargo, y a diferencia de la trama novelesca, dicho conjunto no se encamina hacia la expresión de las formas de confrontación entre ambos sistemas. Pone de manifiesto la contraposición de dos memorias distintas, de dos concepciones opuestas de la identidad propia, y de dos proyecciones diferentes del presente y el futuro sobre el pasado y viceversa. Pero no se trata, obviamente, de que una de estas dos visiones sea 
más genuinamente "indígena" que la otra: ambas dan cuenta, aunque de muy distinta manera, de una rearticulación de las dos culturas en contienda desde la Conquista y. la colonización: la occidental y cristiana por un lado, y la indígena por el otro. Por lo mismo, lo que hace la diferencia fundamental entre estas visiones no descansa en el origen de las representaciones que articulan; radica en sus respectivas estructuras cognitivas y éticas: en sus diferentes concepciones acerca de la verdad, de los vínculos entre ésta y las formas del tiempo, entre ésta y el "otro" o los "otros," y de ésta con uno mismo. Por un lado, encontramos entidades fijas y acabadas, una lógica de la confrontación y el poder, y una evolución temporal lineal, que fija inexorablemente el pasado y la memoria y desemboca en una circularidad trágica. Por el otro lado, vemos perfilarse identidades fundadas en la ponderación de las acciones propias y ajenas, en el cumplimiento de los ciclos vitales de cada ser y de cada ámbito particulares, y en los entrecruzamientos de espacios y temporalidades diversas; esto es, una forma de identidad subjetiva siempre inacabada, abierta a la verdad del otro y a la reintegración actual de las vivencias y las experiencias pasadas.

A la memoria cristalizada y sellada de la crónica y el relato histórico-genealógico se anteponen la memoria vivencial, la analogía "poética," y la ambigüedad del relato mitológico, cuya conjunción de certeza y misterio se nutre de la incesante renovación de los ciclos vitales. Así es entonces como estas dos formas contrastadas de la temporalidad, de la identidad y de la memoria, pueden desembocar en dos concepciones igualmente contrastadas de la herencia: por sobre "la herencia de Mario, el varón," fundada en un supuesto derecho de casta, se privilegia el solidario legado cultural de la nana, que habrán de recoger juntas la niña, la narradora y la autora.

\section{El cuestionamiento de la tradición realista y el relato autobiográfico}

Ahora bien, la contraposición -en la primera parte de la novela - de estos dos universos de representaciones anticipa el cambio de modalidad narrativa de la parte central, preparado de otro lado por imágenes y escenas que contribuyen a precisar la función de dicho cambio. Las dos evocaciones de la niña en el relato distanciado de la parte central, a las que nos hemos referido ya, se hallan prefiguradas y fusionadas en el capitulo $\mathrm{X}$ de la primera parte, a propósito de la muerte del indio acusado de traición a su raza y de la conmoción que se apodera de la niña ante el horror del castigo:

Las ventanas de mi cuarto están cerradas porque no soporto la luz. Tiemblo de frío bajo las cobijas y sin embargo, estoy ardiendo en calentura. La nana se inclina hacia mí y pasa un pañuelo humedecido sobre mi frente. Es inútil. No logrará borrar lo que he visto. Quedará aquí,adentro, como si to hubieran grabado en un lápida. No hay olvido. (...) No, no, no es eso. Es mi padre recostado en la hamaca del corredor, leyendo. Y no mira que lo rodean esqueletos sonrientes, con una risa silenciosa y sin fin. Yo huyo, despavorida, y encuentro a mi nana lavando nuestra ropa a la orilla de un río rojo y turbulento. De rodillas golpea los lienzos contra las piedras y el estruendo apaga el eco de mi voz. Y yo estoy llorando en el aire sordo mientras la corriente crece y me moja los pies. $(31-33)$ 
Las reiteraciones de la imagen de la niña llorando ante la violencia de las confrontaciones que rechaza - y que ella y la narradora asocian metafóricamente con la corriente del río y la privación de voz por un lado, y con la presencia (o la ausencia) de la nana por el otro- configuran un motivo recurrente que, más allá de las diferencias de modalidad enunciativa, une entre sí las dos primeras partes de la novela. La asociación parcial de esta misma imagen (la del llanto y la privación de voz) con la partida para Chactajal y la separación de la nana después de que ésta hiciera a "su niña" la entrega sagrada de una "herencia" en todo opuesta a "la de Mario, del varón" -objeto, esta última, de la sangrienta confrontación relatada en la parte central-permite pensar que, en el plano de la composición de la obra, existe una contraposición entre las dos primeras partes de la novela que pudiera resultar análoga a la que sugiere el contrapunto entre las dos "herencias" y sus respectivos lenguajes.

\section{a) El problema del indigenismo y el realismo mágico}

Por su forma composicional, el relato central, que para algunos críticos ha servido de base para la adscripción de la primera novela de Rosario Castellanos a la corriente del indigenismo, obedece sin duda a la modalidad de la narración realista. Narrado en tercera persona y en pasado, orientado hacia la reconstitución de un conflicto social centrado en la propiedad de la tierra, y enmarcado en un periodo histórico concreto (el del Cardenismo), dicho relato descansa en la configuración de "personajes típicos en situaciones típicas," y reproduce (hasta cierto punto al menos, como veremos enseguida) lo que podía entenderse entonces como las tendencias del proceso histórico: la irrupción de los sectores populares en la escena política y el quiebre del sistema de tenencia de la tierra heredado de la Colonia en el marco de un régimen político de tintes populistas.

Sin embargo, mientras el indigenismo (el hispanoamericano al menos) buscaba adherirse a las reivindicaciones de los sectores indígenas acorralados por la reestructuración del sistema de tenencia de la tierra impulsada por la "modernización," en la confrontación planteada por el relato central de Balún_Canán y su desenlace, el acento se desplaza hacia el desmoronamiento de los terratenientes, hacia sus zozobras, sus ardides y sus componendas. Asimismo, la sublevación indígena ya no desemboca en el señalamiento - mítico o no- de una perspectiva colectiva de futuro: los indigenas se dispersan y se pierden de vista mucho antes de que concluya el relato, con una frase que, por lo demás, no deja lugar a dudas acerca de quienes constituyen el foco primordial de la atención del narrador: "Esa misma noche los Argüellos regresaron a Comitán" (216). No queremos decir con ello que el relato minimice el papel de la rebelión indígena, sino que, lejos de conducir a una reivindicación de los sublevados, la confrontación planteada termina disolviéndose y acarreando una doble dispersión: la de los indigenas primero, con los que no llega nunca a identificarse la voz enunciativa; y la de los Argüello después, cuya identidad familiar y de casta aparece definitivamente rota, no sólo por la pérdida de la hacienda familiar en la que aquélla se sustentaba, sino también por la extinción de su rama varonil y los extravíos de su rama femenina. De modo que la perspectiva ideológica, que unas pocas décadas antes alimentaba el movimiento indigenista y su literatura, no llega a perfilarse en el relato 
central de Balún Canán. De este movimiento, o mejor dicho, de la novela indigenista y realista, la narradora chiapaneca retiene la forma composicional, mas no la perspectiva ideológica que la alentaba.

Al distanciamiento formal implícito en el abandono de la narración en primera persona y en la aparición del "se" impersonal al que se atribuye el relato central, parece entonces sumarse otro respecto de la tradición narrativa a la que con todo está apelando la autora en esta parte de la novela. La disolución manifiesta del vínculo orgánico entre la forma composicional de la novela indigenista y la perspectiva ideológica que regía la orientación de sus contenidos, convierte de hecho al relato central de Balún Canán en una estilización de aquella modalidad novelesca. Pero en esta estilización, la acentuación de los principales rasgos composicionales de la forma estilizada se conjuga con un desvío de sus orientaciones ideológicas acostumbradas, sin llegar por ello hasta la parodia. No hay en el distanciamiento buscado ninguna intención burlesca, ningún tono o acento que puedan mover a risa (ni leve siquiera). El propósito, y la motivación profunda, de esta puesta a distancia son de otra naturaleza. Sobre ello, volveremos más adelante.

Otro aspecto del desvío que venimos analizando, atañe a la forma del sujeto de la narración. La narración realista no se caracteriza por la sola configuración de "personajes típicos en situaciones típicas." Esta modalidad particular de configuración de acciones y personajes se asocia por lo general con una narración en tercera persona, que presupone la universalidad objetiva de la representación. La estilización en cambio entraña cierto distanciamiento del sujeto de la escritura respecto de la forma estilizada. Con ello, ésta pierde no sólo su estabilidad semántica, sino también su valor de verdad acabada y única. En este caso, el valor relativo de la narración central está señalado de entrada por la frase que la encabeza: "Esto es lo que se recuerda de aquellos días" (75). Y, por lo demás, el hecho de que este relato central se presente flanqueado por formas distintas de rescate de la memoria y otras modalidades narrativas (el uso de la primera persona en las hojas laterales del tríptico), contribuye también a restarle objetividad y valor de verdad indiscutible.

En efecto, la puesta a distancia del relato central y el valor relativo de las verdades que enuncia no pueden desligarse de las diversas modalidades de formalización de la memoria que la primera parte de la novela venía contrapunteando, puesto que, desde su epígrafe, dicho relato se presenta como otra forma más de la memoria. Con todo, en esta presentación liminar, dos aspectos llaman la atención: el uso del presente en el verbo recordar, que contrasta con el pasado de la narración que introduce; y el "se," a la vez impersonal y colectivo, con el cual se figura el sujeto de la narración, el cual se contrapone al "yo" que hasta entonces había venido recordando y narrando. Todo parece indicar entonces que dicho relato consiste en la reelaboración literaria y estilizada de una memoria histórica y familiar viva aún, de la que la narradora —o más bien, el sujeto de la escritura novelesca-quisiera deslindarse. De ahí la posición a la vez meridiana y como en trasfondo que ocupa este relato histórico-familiar en el tríptico al que — pensamos- puede asimilarse la novela de Rosario Castellanos. 
Ahora bien, quedaría por precisar a quién, o a quiénes, podría pertenecer este "recuerdo," vivo todavía, que el sujeto de la escritura novelesca somete a una cuidadosa reelaboración y estilización literarias. Hasta ahora, hemos insistido en la huella de una poética realista (basada en la posición externa del narrador y en la configuración "típica" de personajes y acciones) y en la ausencia de adhesión a la perspectiva histórica que pudiera haber planteado la sublevación de los indígenas. $\mathrm{El}$ núcleo temático anudado en torno a la confrontación por la tenencia de la tierra y las caracterizaciones de los indigenas como la que transcribimos a continuación (que bien pudiera estar sacada de Huasipungo (1934), la novela de Jorge Icaza) confirman la primera de estas observaciones:

Los hombres entraban tambaleándose en la ermita y se arrodillaban al lado de las mujeres. Con los brazos extendidos en cruz conservaban un equilibrio que su embriaguez hacía casi imposible y balbucían una oración confusa de lengua hinchada y palabras enemistadas entre sí. Lloraban estrepitosamente golpeándose la cabeza con los puños y después, agotados, vacíos como si se hubieran ido en una hemorragia, se derrumbaban en la inconsciencia. Roncando, proferían amenazas entre sueños. Entonces las mujeres se inclinaban hasta ellos y, con la punta del rebozo, limpiaban el sudor que empapaba las sienes de los hombres y el viscoso hilillo de baba que escurría de las comisuras de su boca. Permanecían quietas, horas y horas, mirándolos dormir. $(127-128)$

Por su parte, el marcado desequilibrio entre, por un lado, la caracterización de los personajes indígenas - siempre vistos desde fuera y sin espesor ni complejidad subjetiva (el lider de los indígenas es buen ejemplo de ello) - y, por otro, la tendencia del sujeto de la enunciación a colocarse en la perspectiva subjetiva de quienes pertenecen al ámbito de los hacendados (con un frecuente recurso al monólogo interior), contribuyen a resaltar uno de los principales rasgos estructurales de la novela indigenista: la imposibilidad en la cual se hallaba el narrador para calar en una cultura y en formas de subjetividad que le eran en buena medida ajenas. Y subraya al mismo tiempo el traslado de la focalización hacia el otro polo de los sectores sociales en contienda. Unas pocas páginas antes de la cita anterior, el siguiente tratamiento del personaje de Matilde puede servir para corroborar nuestras aseveraciones:

Si, era verdad. Matilde se sentaba en la orilla del estrado, presta a huir, a correr, a la menor insinuación de que su presencia sobraba en esta casa. Pero ¿adónde iria? Y entonces no se le alcanzó más que tratar de ocultar su presencia para no dar molestias a los demás. La hora de comer -que era cuando todos se reunian - significaba para ella una tortura. Con el pretexto de vigilar el servicio no se sentaba en la mesa. Las primeras veces su conducta les pareció extravagante y la instaban a que les acompañara. Pero luego fue volviéndose natural el hecho de que Matilde comiera después en la cocina, con la servidumbre. Y aun alli los bocados se le atragantaban, no podía bajarlos. Desalentada retiraba su plato. (120) Respondió instintivamente, sin pensarlo, sin intención de ofender. Y ahora Matilde callaba, horrorizada de haber sido capaz de pronunciar esas palabras. Pero ella no tenía la culpa, de veras. Emesto la había obligado. ¿En qué forma había ella provocado a Ernesto para que viniera a sacudirla con esa violencia, con esa brutalidad, con ese odio? (122) 
Aunque, en estas citas, la voz enunciativa pertenece sin duda al narrador externo, la adopción de una perspectiva "desde dentro" del personaje y las inflexiones de la "palabra" interna de este último en la voz enunciativa son bastante claras. Lo que, desde luego, no conlleva que, aqui como en el monólogo interior, la configuración del personaje deje de obedecer a los designios del narrador. La contaminación del estilo de este último por la palabra interna del personaje, e incluso la momentánea desaparición del narrador para dejar lugar al monólogo interior del personaje, son recursos que pertenecen a la tradición realista y que no contradicen su prurito de "objetividad." Dentro de los límites fijados por este último, el ir y venir del narrador de lo "externo" a lo "interno" y viceversa, con todos los grados y matices que ello pueda conllevar, es parte de la "tipificación" y la caracterización sin duda conflictiva de los protagonistas y las acciones que constituyen el objeto de la representación artística por parte del narrador externo.

A esta misma tradición realista - a la hispanoamericana al menos - pertenecen también párrafos como éstos, en los que no es muy difícil advertir el eco del llamado realismo mágico, y de Miguel Ángel Asturias en particular (Hombres de Maiz se publica por primera vez por Losada en 1949):

Los que por primera vez conocieron esta tierra dijeron en su lengua: Chactajal, que es como decir lugar abundante de agua.

El gran río pastor llama, con su voz que suena desde lejos, a los riachuelos tributarios. Ocultan su origen. Se manifiestan después cuando vienen resbalando entre las peñas musgosas de la montaña, cuando abren su cauce arando pacientemente la llanura. Pero desde que nacen llevan su nombre, su largo nombre líquido-Canchanibel, Tzaconejá-, para entregarlo aquí, para perderlo y que se enriquezca la potencia y el señorío de Jataté (...)

Los que por primera vez nombraron esta tierra la tuvieron entre su boca como suya. $Y$ era un sabor de mazorca que dobla la caña con su peso. Y era la miel espesa y blanca de la guanábana. Y la pulpa lunar de la anona. Y la aceitosa semilla del zapote. Y el lento rezumar del jugo en el tronco herido de la palmera. Pero también hálito, niebla madrugadora que deja seña de su paso en el follaje (...)

Los que por primera vez se establecieron en este tierra llevaron cuenta de ella como de un tesoro. La extensión del milperío y las otras cosechas. La zona para la persecución del ciervo. La encrucijada donde el tigre salta sobre su presa. La cueva remota donde amenaza el hambre del leoncillo. Y el llano que ayuda la carrera cautelosa de la zorra. $\mathrm{Y}$ la playa donde deposita sus huevos el lagarto. $\mathrm{Y}$ la espesura donde juegan los monos. Y la espesura donde los muchos pájaros aletean huyendo del más leve rumor. Y la espesura de ojos feroces de pisada sigilosa, de garra rápida. Y la piedra bajo la que destila sú veneno la alimaña. Y el sitio donde sestea la víbora (...)

Los que vinieron después bautizaron las cosas de otro modo. Nuestra Señora de la Salud. Este era el nombre de los días de fiesta que los indios no sabian pronunciar. Les era ajeno. Como la casa grande. Como la ermita. Como el trapiche. (192-193)

Aun cuando el lenguaje poético y el ritmo de estos párrafos pudieran evocar un habla indígena y dar así a entender que la memoria de los orígenes a la que apelan pudiera ser también indígena, la construcción de estos mismos párrafos con base en la 
repetición de un mismo sintagma que va modificándose ("Los que por primera vez conocieron ... nombraron ... se establecieron ...) y se transforma luego en "Los que vinieron después bautizaron las cosas de otro modo ... Este era el nombre de los días de fiesta que los indios no sabían pronunciar. Les era ajeno," no deja lugar a dudas acerca de la instancia enunciativa a la que pertenece esta evocación "poética" y estilizada de la "memoria" indígena.

Este es sin duda uno de los momentos en que el sujeto de la enunciación pareciera estar más cerca del mundo indígena. Sin embargo, la memoria colectiva aquí atribuida a los indígenas sigue siendo parte de su caracterización externa, y por lo demás su estilo no deja de evocar el tono inicial de la supuesta crónica del hermano mayor. Por lo mismo, y aun cuando este punto pudiera aparecer como el de mayor proximidad del sujeto de la enunciación respecto de la niña y la narradora de la primera y la tercera partes debido a la elaboración poética de la memoria indígena, es también el que marca el deslinde del sujeto de la escritura novelesca -el que reelabora y estiliza la memoria histórica y familiar en el marco de la tradición literaria hasta entonces vigenterespecto del llamado realismo mágico. En efecto, en éste (que no ha de confundirse con la poética de lo "real maravilloso," que busca precisamente superar el problema), la elaboración poética de la memoria y la mitología indigenas por parte de un narrador externo sigue concibiendo a una y otra como atributos de sectores sociales específicos. En Balín Canán en cambio, la continuidad sentada entre la protagonista, la narradora y la autora (en tanto sujeto de la escritura) empeñada en reabrir el pasado, en reactualizar sus vivencias, y en reinterpretarlas a la luz del legado solidario de la nana, se contrapone con aquellas formas consolidadas de la memoria familiar, social, cultural y literaria que el relato central coloca en trasfondo, estilizándolas y poniéndolas a distancia.

\section{b) El problema de la forma autobiográfica}

La narración en primera persona - en la primera y la última partes de Balún Canánemparentan a la novela de Rosario Castellanos con el relato autobiográfico. Incluso, varios de sus aspectos temáticos - el ambiente familiar y la historia fundada en la genealogía y el derecho de casta- podrían vincularla con lo que, a partir de la tradición europea, Marthe Robert definió alguna vez como la "novela de los orígenes y los orígenes de la novela." En dicha tradición, que según la autora proviene de Cervantes y Daniel Defoe, las formas más "desarrolladas" vendrían a ser la novela de aprendizaje o de formación (Bildungsroman), y el realismo psicológico del siglo XIX.

En su versión autobiográfica, basada en la identidad parcial -implícita en el uso de la primera persona - del protagonista y el sujeto de la enunciación, la reconstrucción - en pretérito - del pasado del protagonista es, al mismo tiempo y no sin conflictos desde luego, la historia de la construcción del "yo" a quien pertenece la enunciación presente. En esta concepción particular de la relación entre la identidad actual del "yo" de la enunciación y la reconstrucción de las circunstancias, los acontecimientos y las transformaciones que han marcado la trayectoria del protagonista, la historia y la 
memoria se funden en un relato, cuya forma termina siendo en buena medida especular.

Ahora bien, como lo hemos señalado ya, la primera y la tercera parte (con variantes ésta última, como veremos enseguida) de Balún Canán están enunciadas en primera persona. Sin embargo, la narración no hace uso del pretérito, sino del tiempo presente. Antes que sucesos y acontecimientos que permitieran acotar las transformaciones sucesivas de la protagonista, las diversas escenas evocadas, en forma puntual y sin aparente relación temporal o causal entre sí, tienen ante todo el valor de vivencias o de reminiscencias sueltas, que propician relaciones específicas entre la niña de ayer y la narradora de hoy. En la medida en que esta última no se halla reconstruyendo el pasado sino restituyendo y explorando vivencias, libera a la memoria de los constreñimientos del relato; esto es, de la necesidad de ordenar los sucesos y sus significados en función de un proceso que culminara en la enunciación presente: devuelve actualidad y vigencia a un pasado que permanece semánticamente inacabado y abierto. En otras palabras, la memoria deja aquí de fusionarse con la historia y el relato para confrontarse en cada momento con ellos.

Esta modalidad particular del funcionamiento de la memoria en relación con la historia y el relato se halla sugerida de algún modo desde el capítulo inicial de la novela por aquella confusa sensación de miedo que embarga a la niña ante la gran mesa familiar vacía que ella (¿o la narradora?) asocia con la imagen de un espejo oculto:

Pero si comer es horrible. Ante mi plato mirandome sin parpadear. Luego la gran extensión de la mesa. Y después ... no sé. Me da miedo que del otro lado haya un espejo. (10; el subrayado es nuestro)

Desde luego, la significación de este "espejo" no está precisada de entrada ("Y después ... no sé"). Pero, por cuanto el miedo aquí expresado presupone la no coincidencia del ser ni consigo mismo, ni con la ley simbolizada por la gran mesa familiar — calificada con antelación de "injusta"-, la imagen del espejo introduce un doble cuestionamiento, que habrá de anudarse en torno al lenguaje: en primer lugar, el de la identidad de la niña, desgarrada desde la escena inicial entre dos mundos y dos sistemas de valores unidos y contrapuestos; y luego, e indisociable del anterior, el de la forma del objeto de la representación novelesca. El "plato sin parpadear" y la "gran extensión de la mesa" -asociados confusamente con la imposición de un orden injusto del que uno y otra son el espejo sin nombrar--, sugieren la posibilidad de otro espejo, en donde las imágenes reflejadas pudieran no ser ni tan fijas ni tan lisas. En las eventuales transgresiones implicadas en este juego de espejos, es sin duda en donde se origina el miedo de la niña, empeñada en sacudirse la injusticia. Pero es también en donde se fundan las búsquedas propias de la poética narrativa de Balún Canán.

Desde luego, es la niña de ayer quien brega por sortear las imposiciones de una sociedad marcada por el predominio del conquistador, del hacendado y el varón, el cual priva a indios y mujeres de identidad y voz propias. $Y$ es también la niña, quien intuye en las enseñanzas de su nana indígena el apoyo afectivo y moral necesario para sortear estas imposiciones. Pero no es ella sino la narradora de hoy, quien busca desentrañar las implicaciones cognitivas y éticas del legado cultural de la nana, y quien 
adopta formas de narración puntuales y yuxtapuestas, encaminadas a la liberación de la memoria y a la restitución de las vivencias pasadas. A su vez, la diversificación de los lenguajes (orales y escritos), la inscripción de los significados en ciclos y temporalidades diferenciadas, la búsqueda de imágenes, metáforas, analogías y sistemas de transcodificaciones diversos, propician la retroalimentación entre pasado y presente y la apertura de los significados. De esta manera, el texto instaura una zona intermedia entre la narración y la escritura, dentro de la cual esta última es la que decide del régimen de la voz enunciativa y su mayor o menor proximidad con la de la niña y protagonista; vale decir, del tono y el estilo de la narración. Y la escritura es también la que hila y teje, sin amarrarlas, las coordenadas entre los diversos significados liberados por la reminiscencia. Conjurado ya el miedo infantil, la escritura es, así pues, la que se encarga de explorar la otra faz de aquel espejo oculto intuido por la niña, aunque ella no pudiera ubicarlo con claridad, ni mucho menos descifrarlo.

En cuanto a la autora (en tanto sujeto de la enunciación novelesca), es quien preside a la composición de la obra: a la distribución textual de los materiales, a la configuración de las modalidades cambiantes de la relación entre historia, relato y memoria, y a la inscripción de la problemática así delineada en el marco de tradiciones narrativas diversas (letradas o no). Y, en este mismo marco composicional, es también la que coloca a quien lee ante la necesidad de dialogar activamente con una obra que rompe deliberadamente con el principio de la representación mimética.

De la misma manera que la continuidad entre la niña de ayer, la narradora de hoy y la autora de la obra no se reduce a la de la persona física, tampoco conduce a la construcción de un relato especular. Al basarse en la reminiscencia y en la restitución de vivencias sueltas, la relación entre la narradora y la niña abre la posibilidad de una exploración - tan azarosa y discontinua como lo permiten los mecanismos de la rememoración - de las múltiples facetas de espejos puestos a "parpadear." Contribuye así a que aflore lo que subyace por debajo de la ley inexorable y uniforme del Padre y ha de entrar en la justa ponderación de las acciones.

A su vez, la composición y el estilo de la obra, basados en la versatilidad de la voz enunciativa y el contraste de formas narrativas que constituyen otras tantas formas individuales o colectivas de relatar y guardar memoria, conllevan un cuestionamiento de la representación del pasado - histórico, familiar y personal- y conducen al reconocimiento de la multidimensionalidad de lo real en que ha de fundarse la adopción de cualquier juicio de verdad. Adopción ésta que, por cierto, entraña necesariamente una decisión de orden ético. La de Rosario Castellanos no consiste tanto en prestar su voz a quienes carecen supuestamente de ella $\longrightarrow$ se hallan reducidos a "musitar el origen, la historia y el relato"-, cuanto en hallar una voz propia que, descartando la lógica de la confrontación inherente a la ley del Padre (del Conquistador, el hacendado y el varón), sepa recoger y conferir vigencia, en lo personal y en lo colectivo, a un valioso e insoslayable legado cultural. 


\section{La problemática de la culpa, la heterogeneidad cultural y el conflicto de las interpretaciones}

Desde el punto de vista temático, la tercera parte de Balún Canán, nuevamente ambientada en Comitán, se caracteriza por la ausencia del padre, ocupado en tratar de rescatar parte de su hacienda gracias a hipotéticas amistades políticas; por la enigmática enfermedad de Mario, el hermano menor de la niña y heredero potencial de las tierras de Chactajal; y por la oscura participación de la niña, en lo que termina siendo un desenlace fatal: la muerte del niño, antes augurada por la nana, por lo cual ésta queda despedida sin apelación ninguna. En ausencia del jefe de familia, que deja a las mujeres en el desamparo y la zozobra, la problemática gira en torno a la responsabilidad por la inexplicable muerte del niño varón.

Esta problemática se articula a su vez con la de la culpa, mediante la apelación a diversos universos de representaciones que van desde la brujería o la superstición hasta las explicaciones seudomédicas, pasando por un cristianismo de dudosos ribetes, del que participan de una u otra manera las distintas mujeres de la familia. De modo que, en este clima de zozobra, no sólo la responsabilidad tiende a diluirse, sino que la culpa anda suelta. Volvemos asi, y a propósito de la muerte del hermano menor, a la problemática del "justo peso de las acciones" y al legado de la nana.

\section{a) La alternancia de tiempos verbales}

En esta tercera parte de la novela, la evocación de los sucesos obedece al mismo principio composicional de la primera parte: consiste nuevamente en la yuxtaposición de escenas y capítulos cortos, basados en la reminiscencia de situaciones en las que se halla involucrada la niña y que la narradora recrea tratando de liberar viejos y nuevos significados. Con todo, conviene subrayar que, a diferencia de las reminiscencias de la primera parte, en tiempo presente siempre, las de esta última parte conjugan a menudo, incluso tratándose de una misma escena, dos tiempos verbales distintos: el presente y el pretérito. El valor que el lector ha de atribuir a esta mezcla de tiempos verbales no es siempre fácil de precisar.

En algunos casos, el empleo repentino del pretérito en medio de una escena evocada en tiempo presente pareciera obedecer a una imposibilidad de la narradora de adentrarse en la subjetividad de la persona cuya acción o gesto registra. Así, en el capítulo II, narrado en presente - "Con qué ansia estoy deseando llegar a Comitán para entregarle a mi nana el regalo que le traigo.(...) Mi Madre entra con unos vasos de limonada."- aparece de repente esta notación: "Mi padre bajó la cabeza y se quedó mirando, meditativamente, la punta empolvada de sus botas (...). Se dieron la mano sin hablar. Salieron, uno detrás del otro, hasta la calle." (220-222; los subrayados son nuestros) Luego de lo cual, y casi sin transición, la voz narrativa vuelve al presente: "En cuanto nos dejaron solas, mi madre, ayudada por la nana, comenzó a preparar el equipaje (...) Apartan las camisas. Escogen lo que mi padre va a precisar en su viaje y lo que no." (223)

Con todo, la imposibilidad, o la renuencia de la narradora a colocarse dentro de la subjetividad de la persona a la cual se refiere (en el caso anterior, el padre) no parece 
ser el único mecanismo que opera en los usos repentinos del pretérito. Llama la atención, entre otros, el hecho de que también el despido de la nana esté narrado en pasado, luego de la siguiente evocación, en presente, de la madre mirándose en el espejo (cap.IV):

Se acerca al espejo. Se palpa en esa superficie congelada, se recorre con la punta de los dedos, satisfecha y agradecida. De pronto las aletas de su nariz empiezan a palpitar como si ventearan una presencia extraña en el cuarto. Violentamente, mi madre se vuelve.

- ¿Quién está ahí?

De un rincón sale la voz de mi nana y luego su figura.

-Soy yo, señora.

Mi madre suspira, aliviada.

- Me asustaste. Esa manía que tiene tu raza de caminar sin hacer ruido, de acechar, de aparecerse donde menos se espera. ¿Por qué veniste? No te llamé.

Sin esperar respuesta, pues ha cesado de prestarle atención, mi madre vuelve a mirarse en el espejo No, a mi madre no le simpatiza esta mujer. Basta con que sea india. Durante los años de su convivencia mi madre ha procurado hablar con ella lo menos posible; pasa a su lado como pasaría junto a un charco, remangándose la falda. (228-229)

Sin duda alguna, esta escena de la madre ante el espejo, y las notaciones que la acompañan, han de vincularse con la anterior mención de aquél "otro lado" del espejo que la niña y la narradora asociaban con el miedo al inicio de la novela: reiteran la distancia infranqueable entre la madre y la nana, o entre el mundo de los hacendados y el de los indígenas. En la presente escena, el "otro lado" se concreta de pronto con la referencia de la nana al augurio de los ancianos de la tribu de Chactajal y a la resolución de los brujos de "condenar" a Mario. A esta mención, hecha por la nana atribulada, sucede de inmediato el empleo del pretérito:

(...) Los ancianos de la tribu de Chactajal se reunieron en deliberación. Pues cada uno habia escuchado, en el secreto de su sueño, una voz que decia: "que no prosperen, que no se perpetíen. Que el puente que tendieron para pasar a los días futuros, se rompa.' Eso les aconsejaba una voz como de animal. $Y$ asi condenaron a Mario.

Mi madre se sobresaltó al recordar:

-Los brujos...

- Los brujos se lo están empezando a comer.

Mi madre fue a la ventana y descorrió, de par en par, las cortinas. El sol de mediodía entró, armado y fuerte.

-Es fácil cuchichear en un rincón oscuro. Habla ahora. Repetí lo que dijiste antes. Atrévete a ofender la cara de la luz.

Cuando respondió, la voz de mi nana ya no tenía lágrimas. Con una terrible precisión, como si estuviera grabándolas sobre una corteza, como con la punta de un cuchillo, pronunció estas palabras:

- Mario va a morir. (230-231)

Luego de que queda violentamente despedida la nana, la escena y el capítulo terminan con la imagen trizada del rostro de la madre en el espejo, y con la de la niña 
acercándose silenciosamente a la nana aniquilada, sin que por ello la narración vuelva al empleo del tiempo presente:

Mi madre la soltó y fue a sentarse sobre el banco del tocador. Respiraba con ansia y su rostro se le había quebrado en muchas aristas rígidas. Se pasó un pañuelo sobre ellas, pero no pudo borrarlas.

Silenciosamente me aproximé a la nana que continuaba en el suelo, deshecha, abandonada como una cosa sin valor. (232)

En esta escena, como en otras más adelante, el uso del pretérito parece estar asociado a la violencia de una confrontación que, no sólo confiere a las acciones un carácter irrevocable, sino que traba cualquier posibilidad de despliegue de la emoción y de exploración de la afectividad: quedan registrados los hechos junto con el congelamiento de la remembranza y el cuasienmudecimiento de la voz, 0 al menos de aquella voz abocada a la recuperación de las vivencias pasadas. De tal suerte que las alternancias de tiempos pasados y presentes en esta tercera parte, marcada por el temor y la violencia suscitados por la enfermedad y la muerte del niño y heredero varón, parecieran confurmar el valor atribuido a la ruptura de voz y tiempo enunciativos entre las dos partes anteriores. Asimismo, las dos evocaciones últimas y casi contiguas de la nana y el hermano irremediablemente perdidos, señalan, mediante la vuelta al uso del tiempo presente, el despertar de un "ánimo" más sosegado, capaz de sobreponerse a la violencia de los acontecimientos relatados, y de dar cabida al recuerdo y al examen de la propia culpa.

\section{b) El problema de la heterogeneidad cultural y el conflicto de las interpretaciones en la poética de Balún Canán}

Enlazado con el diálogo entre pasado y presente - cuyos alcances y limitaciones están regulados por los usos diferenciados de los tiempos verbales correspondientes-, el examen de la propia culpa descansa en una reconstrucción de los acontecimientos y de la participación de cada quien en ellos. Pero más que obedecer a una lógica causal destinada a "explicar" el encadenamiento de los hechos y a deslindar responsabilidades en el desenlace fatal, dicha reconstrucción busca ante todo evocar conductas impulsadas por la zozobra. Por lo mismo, estas conductas dejan aflorar universos de representaciones culturales sumamente heterogéneas, y hasta contradictorias entre sí. Privado de la presencia y la autoridad del padre, el universo familiar, ahora regido por las mujeres, no sólo deja traslucir lo que esta autoridad y las formas de dominación implicadas en ella mantenian oculto (la otra faz del espejo ahora trizado), sino que pone de manifiesto el modo subrepticio en que estas formas de dominación actúan incluso en lo que se vive como transgresión. Si las creencias y los rituales cristianos pueden coexistir con las diversas formas de superstición y brujería en las representaciones de unos y otros -e incluso fusionarse en la imaginación de los niños con los cuentos con que las criadas buscan espantarlos y sujetarlos- es porque, a diferencia de los cuentos y la religiosidad de la nana, todas estas formas heterogéneas y soterradas del imaginario social reproducen, cada una a su manera, una misma estructura semántica: asocian la transgresión con el terror; esto es, con la idea de la culpa y el castigo, inculcados por la Colonia. 
$\mathrm{Si}$, en la lectura, nos atuviéramos al solo orden de los acontecimientos y a sus posibles causas, la inexplicable muerte de Mario podría interpretarse de muy diversas maneras, según el universo de representaciones que privilegiáramos: como obra de los brujos de Chactajal, como castigo divino, como impericia o ineptitud del médico, o incluso como resultado de la obstinación de la niña en no permitir la "salvación" de su hermano con la devolución de la llave del oratorio, escondida en el baúl de la nana. Todas estas interpretaciones, barajadas mediante la evocación de las diversas conductas y las representaciones que las guían, dejan en realidad el problema de la explicación "última" completamente abierto. Acaso porque éste no constituye el objeto principal de la narración y la representación artística, pero sobre todo porque ambas se erigen deliberadamente en contra de cualquier forma de clausura del pasado y de cancelación del vínculo con una memoria que ha de permanecer abierta para mantenerse viva y creativa. Así es como el deseo de "perdón" - última palabra de la niña y de la novela, asociada con el deseo anticipado de escritura-- y el valor catártico conferido al rescate de la memoria solidaria responden juntos al deseo de impugnar, y dejar atrás la execrada lógica de la confrontación y la culpabilización, que no sólo paralizan y desquician, sino que desembocan inexorablemente en la reiteración del mismo círculo, tan nefasto como estéril.

\section{Notas}

${ }^{1}$ Para la elaboración de este trabajo, hemos utilizado la edición de la Secretaría de Educación Pública y el Fondo de Cultura Económica, Serie Lecturas Mexicanas, n. 6, México, 1983.

Por otra parte, el presente estudio constituye una ampliación y reformulación del artículo nuestro intitulado "Formas narrativas en Balún Canán de Rosario Castellanos," incluido en las Memorias del Coloquio sobre Narradoras mexicanas contemporáneas y Crítica literaria (México, Colmex, enero de 1993). 